\title{
Perancangan Smart Village Platform Aplikasi Edukatif untuk Pengentasan Stunting serta Monitoring Kesehatan Ibu Hamil
}

\author{
Muhammad Ilham Alhari', Widia Febriyani' ${ }^{2}$, Wader Trisepa Jonson ${ }^{3}$, Asti Amalia Nur Fajrillah ${ }^{4}$ \\ ${ }^{1234}$ Universitas Telkom \\ Email: ${ }^{1}$ milhamalhari@student.telkomuniversity.ac.id, ${ }^{2}$ widiafebriyani@ student.telkomuniversity.ac.id, \\ 3 jhonsonwader@student.telkomuniversity.ac.id, \\ 4astiamalia@telkomuniversity.ac.id
}

\begin{abstract}
ABSTRAK. Era globalisasi erat kaitannya dengan perkembangan teknologi yang menyeluruh di berbagai bidang. Digitalisasi di semua sektor memang tidak bisa dipungkiri lagi, saat ini digitalisasi tidak hanya berkembang di kota saja namun beberapa desa di Indonesia mulai mengembangkan serta membangun desa digital atau dikenal dengan smart village. Namun, hal ini belum berkembang secara optimal. Oleh karena itu, sangat dibutuhkan pengembangan smart village khususnya di bidang kesehatan. Dalam penelitian ini dirancang sebuah platform yang dapat digunakan untuk mengedukasi dengan bantuan platform aplikasi. Metode yang digunakan dalam penelitian ini adalah dengan melakukan survey dengan pihak terkait serta memberikan edukasi program desa untuk monitoring ibu hamil dan balita stunting selain itu penulis juga mengadakan diskusi untuk membantu masyarakat. Harapan dari platform edukasi terkait dengan pengentasan stunting adalah untuk mendukung program nasional untuk penurunan angka stunting di Indonesia.
\end{abstract}

Kata Kunci: stunting; platform edukasi; smart village

ABSTRACT. The era of globalization is closely related to comprehensive technological developments in various fields. Digitalization in all sectors is undeniable, currently, digitalization is not only developing in cities, but several villages in Indonesia are starting to develop and build digital villages, known as smart villages. However, this has not developed optimally. Therefore, it is necessary to develop a smart village, especially in the health sector. In this study, a platform was designed that can be used to educate with the help of an application platform. The method used in this study was to conduct a survey with related parties and provide education on village programs to monitor the stunting of pregnant women and toddlers. In addition, the authors also held discussions to help the community. The hope of the educational platform related to stunting reduction is to support a national program to reduce stunting rates in Indonesia.

Keywords: stunting; education platform; smart village

\section{PENDAHULUAN}

Saat ini Indonesia masih mencoba untuk menyelesaikan terkait permasalahan gizi yang berdampak serius terhadap generasi bangsa terutama dalam sektor kualitas Sumber Daya Manusia (SDM). Salah satu masalah yang menjadi perhatian utama adalah terkait dengan anak balita pendek (Stunting). Stunting adalah kondisi gagal tumbuh balita. Salah satu penyebab stunting adalah faktor lingkungan, atau kurangnya pengetahuan ibu dan cara pola asuh yang salah.

Asupan gizi juga menjadi hal dasar harus diketahui oleh ibu terutama pada 1000 Hari Pertama Kehidupan yang menjadi kunci untuk tumbuh kembang anak (Aryastami \& Tarigan, 2017). Permasalahan yang terjadi pada Kecamatan Mondokan adalah kasus stunting yang terbilang masih cukup tinggi dibandingkan dengan daerah lain. Adapun proses pencatatan dan monitoring edukasi yang dilakukan saat ini masih manual dan belum maksimal yaitu dengan penyuluhan maupun pertemuan kelas ibu hamil ataupun balita,yang selama ini dilakukan oleh bidan desa dalam proses penyampaian edukatif terkait kesehatan balita dan kehamilan.

Berdasarkan data stunting di keccamatan Mondokan per-Agustus 2020 tercatat presentase stunting sebesar 19,71\%. Dalam data tersebut disebutkan bahwa empat desa menjadi lokasi khusus stunting kabupaten Sragen yaitu desa Sono, Jekani, Kedawung dan Sumberejo. Angka prosentase stunting terus meningkat dan ditargetkan untuk turun $14 \%$ pada tahun 2024. Adapun tabel presentase stunting kecamatan Mondokan dapat dilihat dari tabel 3 . 
Tabel 1. Data Prosentase Stunting Kec.Mondokan Agustus 2020

\begin{tabular}{ccccccc}
\hline \hline No & Nama Desa & $\begin{array}{c}\text { Balita } \\
\text { Pendek }\end{array}$ & $\begin{array}{c}\text { Balita } \\
\text { Sangat } \\
\text { Pendek }\end{array}$ & $\begin{array}{c}\text { Total } \\
\text { Stunting }\end{array}$ & $\begin{array}{c}\text { Total } \\
\text { Balita }\end{array}$ & Prosentase \\
\hline 1 & Pare & 57 & 17 & 74 & 364 & $20,33 \%$ \\
\hline 2 & Sono* & 28 & 17 & 45 & 170 & $26,47 \%$ \\
\hline 3 & Tempelrejo & 45 & 9 & 54 & 264 & $20,45 \%$ \\
\hline 4 & Gemantar & 69 & 11 & 80 & 494 & $16,19 \%$ \\
\hline 5 & Jambangann & 53 & 6 & 59 & 305 & $19,34 \%$ \\
\hline 6 & Jekani* & 58 & 21 & 79 & 372 & $21,24 \%$ \\
\hline 7 & Kedawung* & 65 & 24 & 89 & 429 & $20,75 \%$ \\
\hline 8 & Sumberejo* & 36 & 15 & 51 & 184 & $27,72 \%$ \\
\hline 9 & Trombol & 29 & 2 & 31 & 270 & $11,48 \%$ \\
\hline \hline
\end{tabular}

*Daerah Lokasi Khusus Penanganan Stunting Tingkat Kabupaten

elektronik Pencatatan Pelaporan Gizi Berbasis Msyarakat (e-PPGBM) merupakan modul yang digunakan untuk melakukan pencatatan secara elektronik data individu dengan nama dan alamat yang bersumber dari Posyandu (Meidiawani, Misnaniart, \& Syakurah, 2021). Dalam praktiknya sebuah Sistem Informasi Kesehatan yang baik merupakan sistem informasi yang dapat serta mampu untuk menghasilkan data/informasi yang dapat di percaya, akurat serta tepat waktu. Faktanya dalam hal manajemen kesehatan di tingkat kabupaten/kota, provinsi dan pusat, Sistem Informasi aplikasi e-PPGBM ini belum banyak berperan karena belum menghasilkan data/informasi yang akurat dan tepat waktu (Meidiawani, Misnaniart, \& Syakurah, 2021).

Dengan permasalahan yang telah dijelaskan kami melakukan penelitian yaitu terkait dengan konsep Smart village ( Hasibuan, Sutedi, Lestari, Chairani, \& Wasilah, 2021) salah satunya di bidang kesehatan berupa pemanfaatan platform aplikasi digital yang membantu bidan desa atau stakeholder di posyandu untuk melakukan pencatatan secara lengkap, akurat dan tepat waktu selain itu aplikasi ini mampu untuk memberikan edukasi ke ibu hamil dan juga memudahkan bidan dalam melakukan monitoring kesehatan ibu hamil dan balita serta merekap laporan. Tentunya apikasi ini dibuat sebagai upaya membantu menurunkan permasalahan angka kasus stunting di lokasi penelitian.

\section{METODE PENELITIAN}

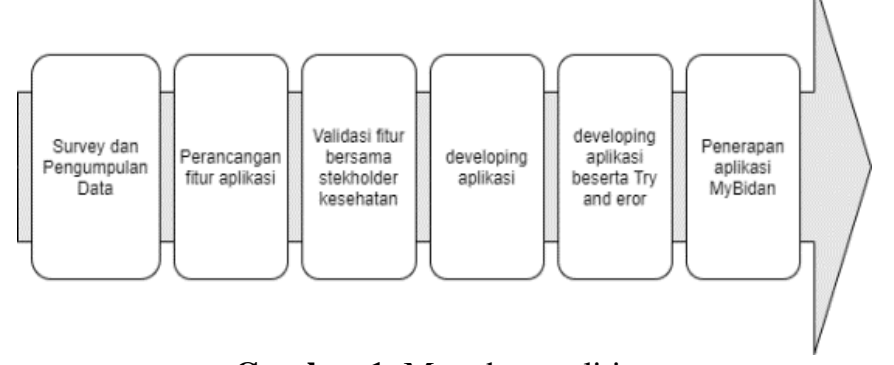

Gambar 1. Metode penelitian

Metode penelitian yang merupakan pondasi ataupun acuan dasar yang akan digunakan dalam penelitian. Metode penelitian yang tersusun secara sistematis dan terstruktur sehingga memudahkan dalam pelaksanaannya untuk itu penulis membagi menjadi beberapa tahapan. yang pertama adalah melakukan survei dan pengumpulan data. Survei ini diawali dengan berhubungan langsung dengan masyarakat sekitar, selain itu penulis juga melakukan identifikasi masalah sekaligus memahami kondisi lapangan.

Pada tahap survey dan pengumpulan data untuk kebutuhan prancangan fitur aplikasi dalam mengangkat konsep Smart Village, pada pembangunan aplikasi edukatif untuk pengentasan stunting serta monitoring kesehatan ibu hamil yaitu dengan teknik mengumpulkan data kebutuhan bahan edukasi sebagai requirement yang dibutuhkan di dalam aplikasi tersebut. Dalam pengumpulan data edukasi dilakukan dengan cara observasi di posyandu, kegiatan penyuluhan bidan desa, informasi berita terkait pencegahan stunting, melakukan 
interview dengan stekholder terkait di bidang kesehatan kemudian dilakukan pengerucutan analisis apa saja requirement yang menjadi fokus utama dalam perancangan aplikasi tersebut, dari beberapa analisis dan pertimbanga diperoleh requirement seperti berikut :

- Menampilkan fitur profil anak dengan fungi mengetahui perkembangan balita dan kandungan

- Menampilkan cek kesehatan ibu di fokuskan pada monitoring kesehatan ibu terkait pencegahan ibu hamil anemia dan ibu hamil kekurangan energi kronis (KEK)

- Mensajikan fitur kelas asuh sebagai media edukasi terkait pencehagan stunting dan edukasi terkait gizi serta pola asuh anak

- Menampilkan fitur artikel dan berita untuk memudahkan user dalam mencari berita terkait kesehatan

- Menampilkan agenda posyandu

- Layanan call canter

Pada perancangan desain aplikasi untuk menggambarkan antara hubungan aktor yang bekerja di dalam aplikasi dengan sistem dapat digambarkan melalui diagram use-case sebagai berikut:

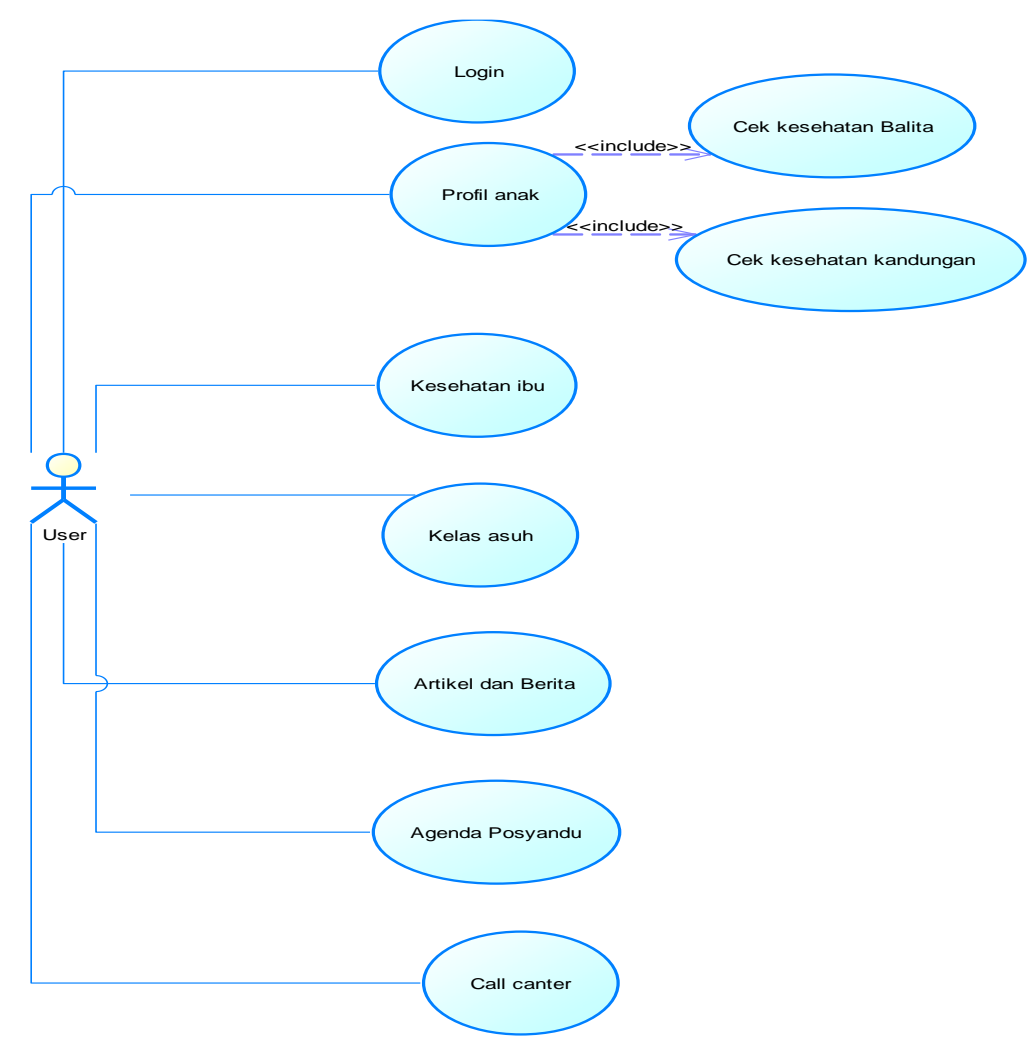

Gambar 2. Diagram use-case user 


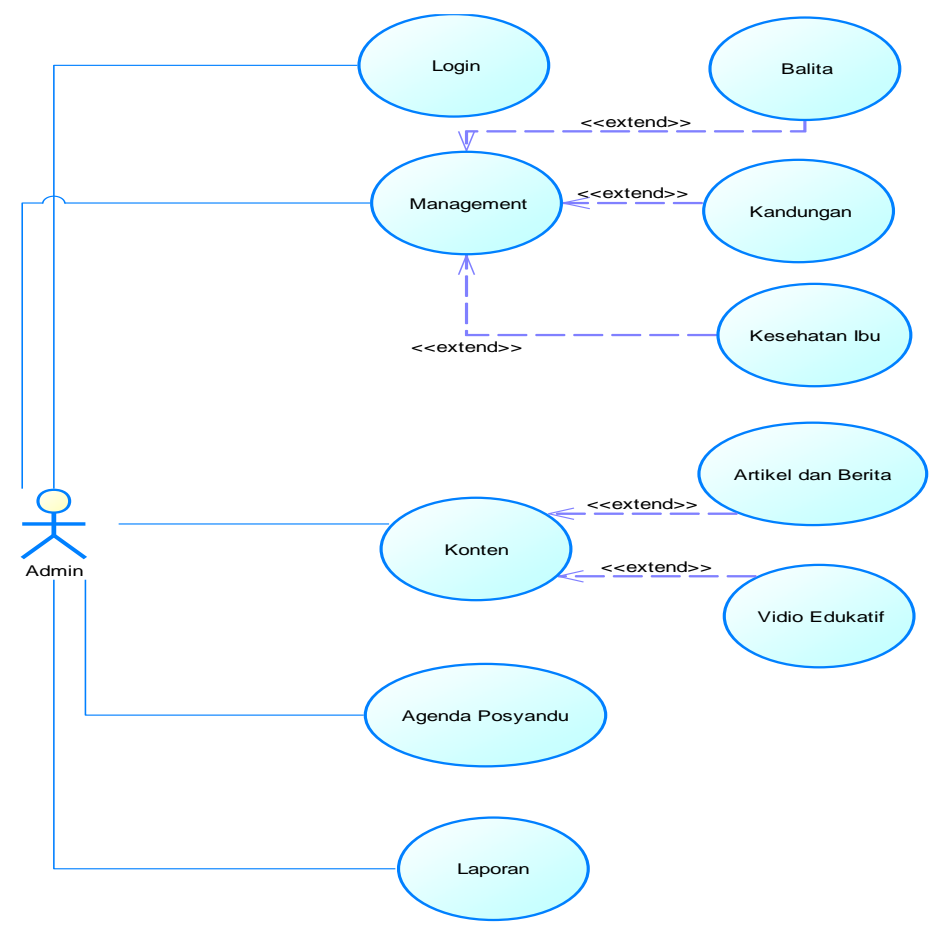

Gambar 3. Diagram use-case Admin

Selain itu kami juga melakukan validasi untuk memastikan bahwa fitur yang kami buat sudah sesuai dan terpercaya. Pada tahapan validasi ini kami juga melakukan forum grup discussion (FGD) bersama dengan stakeholder kesehatan untuk mendapatkan masukan kesesuaian program dalam percepatana penanganan stunting melalui strategi platform aplikasi digital.

Setelah validasi fitur yang dilakukan bersama stekholder maka tahap selanjutnya yaitu masuk ke tahap developing, tahap ini merupakan proses bagaimana cara mewujudkan requiremen yang telah dirancang sebelumnya ke bentuk platform aplikasi, pada tahap developing adapun tools atau kakas yang diperlukan untuk menunjang programer dalam tahap implementasi sebagai berikut.

- Hyper Text Markup Language

- Bahasa pemrograman PHP

- Mysql

- Xampp

- Web browser

- Code editor

- Hosting

- Domain

Perancangan fitur aplikasi dan validasi berjalan sesuai dengan rencana awal. Tim pelaksana pun langsung development aplikasi yang dibutuhkan. Selain itu selama proses develop aplikasi tim terus berkoordinasi dan melakukan evaluasi sebagai bentuk mitigasi risiko yang tidak diinginkan.
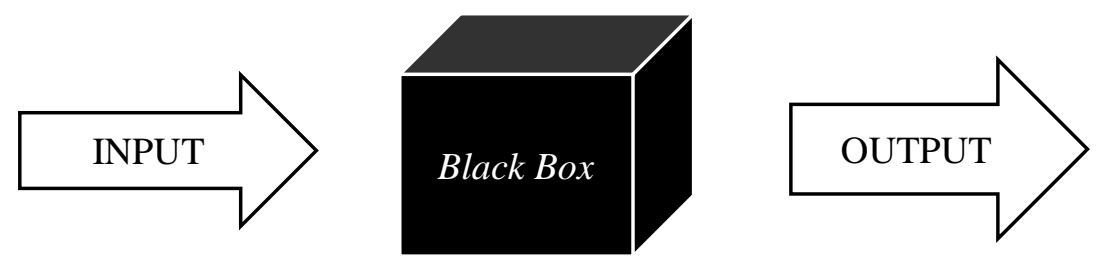

Gambar 4. Black Box Testing 
Pada tahapan pengujian peneliti menggunakan metode Black Box. Black Box Testing atau pengujian fungsional merupakan sebuah metode pengujian Perangkat Lunak yang dapat digunakan untuk menguji perangkat lunak tanpa mengetahui struktur internal kode atau Program (Kurniawati, 2018).

Pada tahap implementasi aplikasi yang telah selesai dibuat dan dinyatakan layak ketika dilakukan pengujian dengan metode black box. Kami melakukan implementasi pada platform aplikasi edukatif untuk pengentasan stunting serta monitoring kesehatan ibu hami di daerah Desa Kedawung, Kecamatan Mondokan , Kabupaten Sragen yang menjadi rolle model program percepatan penanganan stunting dengan media digital dan dalam tahapan implementasi juga memberikan sosialisasi bersama dengan masyarakat guna memberikan pemahaman pentingnya pencegahan stunting sedari dini dengan akses informasi secara digital.

Dari kegiatan ini diharapkan masyarakat dapat memahami dan juga mengimplementasikan serta bisa lebih mandiri dalam menggunakan teknologi. Penulis juga berharap jika dengan menggunakan aplikasi ini dapat meningkatkan minat baca mereka serta pemahaman terutama peduli terhadap kesehatan dan asupan gizi untuk balita dalam rangka untuk mengentaskan stunting.

\section{HASIL DAN PEMBAHASAN}

Pada tahap implementasi aplikasi berbasis web dengan menggunakan teknologi bahasa pemrograman $P H P$ dan MYSQL sebagai database.

Dalam pengujian funsionalitas system dilakukan dengan melalui metode Black box dengan metode ini bertujuan untuk memudahkan dalam mengkaji sebuah kelayakan system dengan fungsionalitasnya sesuai dengan fungsi yang telah di tentukan (Ikhlaashi \& Putro, 2019), pada pengujian ini akan dilakukan pengujian pada fungsi login, cek profil anak, cek kesehatan ibu, artikel, berita, kelas asuh, agenda posyandu, layanan call canter, profil.

Tabel 2. Hasil pengujian login page

\begin{tabular}{llcc}
\hline \hline No & \multicolumn{1}{c}{ Fitur } & Baik & Tidak Baik \\
\hline $\begin{array}{l}\text { 1. } \\
\text { passwontikasi login (username dan }\end{array}$ & $\mathrm{V}$ & \\
& & &
\end{tabular}

Tabel 3. Hasil pengujian cek profil anak

\begin{tabular}{llcc}
\hline \hline No & \multicolumn{1}{c}{ Fitur } & Baik & Tidak Baik \\
\hline 1. & $\begin{array}{l}\text { Cek kesehatan balita (Progres } \\
\text { pertumbuhan) }\end{array}$ & $\mathrm{V}$ & \\
2 & Cek kesehatan kandungan & $\mathrm{V}$ \\
\hline
\end{tabular}

Tabel 4. Hasil pengujian cek kesehatan ibu

\begin{tabular}{clcc}
\hline No & \multicolumn{1}{c}{ Fitur } & Baik & Tidak Baik \\
\hline 1. & Hasil cek kesehatan (lila, HB, IMT) & $\mathrm{V}$ & \\
2 & Status rujukan & $\mathrm{V}$ \\
3 & Keterangan pemerikasaan & $\mathrm{V}$ \\
\hline \hline
\end{tabular}

Tabel 5. Hasil pengujian artikel dan berita

\begin{tabular}{cccc}
\hline \hline No & Fitur & Baik & Tidak Baik \\
\hline 1. & Menampilkan artikel dan berita & $\mathrm{V}$
\end{tabular}


Tabel 6. Hasil pengujian kelas asuh

\begin{tabular}{clcc}
\hline \hline No & \multicolumn{1}{c}{ Fitur } & Baik & Tidak Baik \\
\hline 1. & Menampilkan video & $\mathrm{V}$ & \\
2 & Menampilkan deskripsi & $\mathrm{V}$ \\
3 & Pencarian video & $\mathrm{V}$ \\
\hline \hline
\end{tabular}

Tabel 7. layanan call canter

\begin{tabular}{cccc}
\hline \hline No & Fitur & Baik & Tidak Baik \\
\hline 1. & Menampilkan call canter & $\mathrm{V}$ &
\end{tabular}

Tabel 8. Profil

\begin{tabular}{llcc}
\hline \hline No & \multicolumn{1}{c}{ Fitur } & Baik & Tidak Baik \\
\hline 1. & Menampilkan profil akun & $\mathrm{V}$ & \\
& & & \\
2 & Logout & $\mathrm{V}$ & \\
\hline \hline
\end{tabular}

Setelah melalui tahap pengujian melalui metode Black box, dapat disimpulkan bahwa fungsionalitas fitur sudah berjalan dengan baik dan sesuai dengan alur requirement yang telah di tentukan pada tahap awal perancangan, sehingga aplikasi dapat di implementasikan untuk percepatan penanganan stunting, berikut adalah hasil dari pengembangan platform aplikasi edukatif untuk pengentasan stunting serta monitoring kesehatan ibu hamil

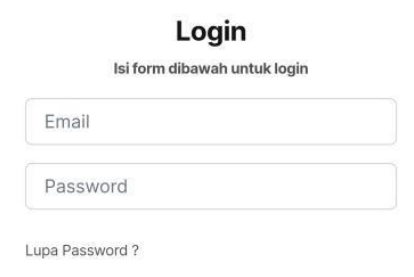

Gambar 5. Halaman Login 
Aplikasi ini dapat diakses langsung melalui browser gadget ataupun pc. Untuk tampilan awal aplikasi untuk masuk silahkan isi form yang diminta aplikasi yang berarti pengguna akan diminta untuk melakukan login terlebih dahulu sebelum menggunakan aplikasi. Adapun hak akses email dan password akan didaftarkan terlebih dahulu oleh admin. Hal ini dilakukan untuk memastikan bahwa yang dapat mengakses adalah orang yang diberi hak akses dan mengurangi adanya penyalahgunaan data. Pada tahapan ini pengguna cukup melakukan login dan apabila pengguna lupa password bisa langsung melakukan klik pada tombol "lupa password". Setelah memasukkan email dan password yang sesuai pengguna langsung diarahkan untuk melakukan klik pada tombol masuk yang berwarna biru.

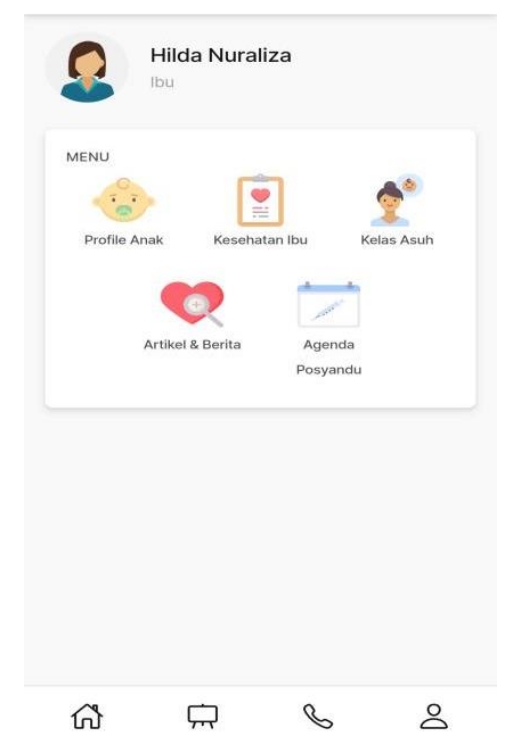

Gambar 6. Tampilan fitur utama

Selanjutnya akan terlihat fitur-fitur yang ada di dalam menu home atau tampilan utama di aplikasi yaitu: fitur profil anak, fitur kesehatan ibu, fitur kelas asuh, fitur artikel dan berita serta fitur agenda posyandu serta layanan call canter.

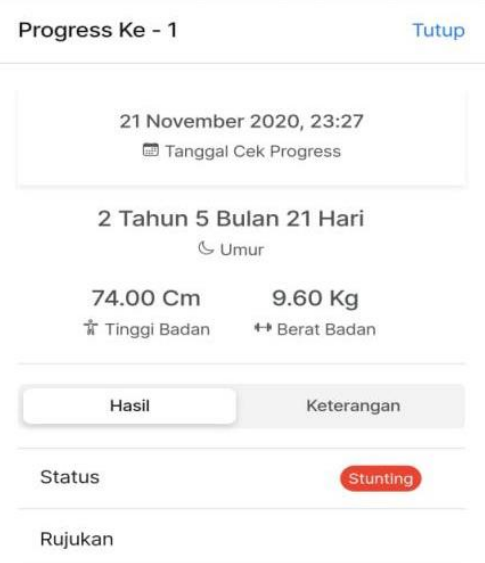

Gamber 7. Fitur profil anak

Gambar berikut merupakan tampilan dari profil anak. Fitur ini memberikan gambaran terkait dengan progress pengecekan serta monitoring kesehatan anak. Adapun data-data yang harus diinputkan antara lain kapan anak dilahirkan berat badan lahir dan panjang lahir. kemudian sistem akan melakukan analisis untuk mengetahui apakah anak tersebut tergolong stunting atau tidak dan juga terdapat menu rujukan yang dapat digunakan oleh bidan untuk memberikan rujukan ke puskesmas maupun rumah sakit terdekat apabila diperlukan. 


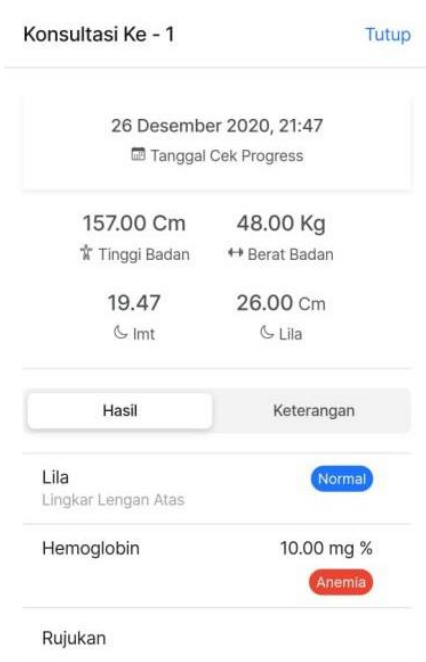

Gambar 8. Fitur Kesehatan Ibu

Gambar diatas merupakan tampilan dari fitur cek kesehatan ibu. Yang harus diinputkan adalah terkait tinggi badan, berat badan, lila, hemoglobin dan imt. dengan melihat fitur ini ibu dapat mengetahui bagaimana kondisi kesehatan dia dan apakah memiliki risiko melahirkan bayi yang stunting atau tidak.

Aplikasi ini juga memiliki fitur agenda posyandu. Pada fitur ini akan memberikan informasi terkait jadwal layanan posyandu.

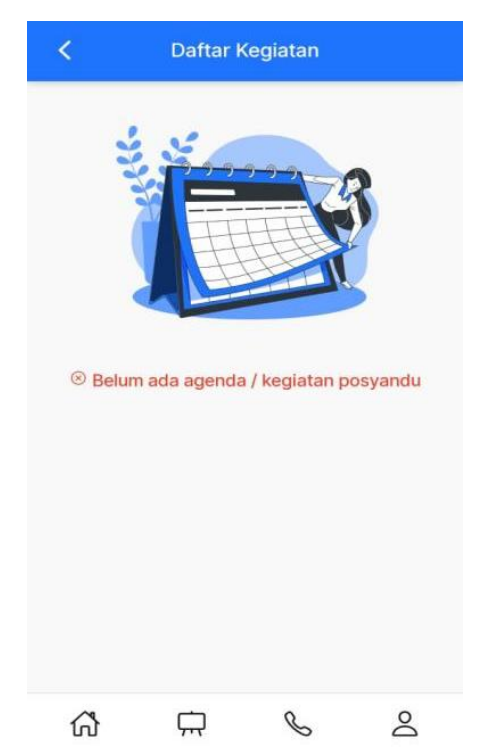

Gambar 9. Fitur agenda posyandu 


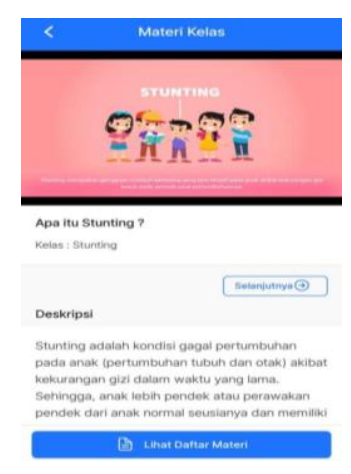

Gambar 10. Kelas Asuh

Selain terdapat fitur jadwal posyandu, aplikasi ini juga memiliki fitur unggulan lain yaitu kelas asuh serta dilengkapi dengan Artikel dan berita. fitur ini berisi video,artikel dan berita yang berisi deskripsi singkat mengenai pemberian edukasi informasi pengetahuan serta sebagai media pembelajaran yang dapat diakses oleh ibu hamil kapanpun dan dimanapun.

Pada menu ini dibuat semenarik mungkin dan berupa video pendek yang berdurasi pendek sehingga para pengguna bisa belajar dengan efektif dan menyenangkan.

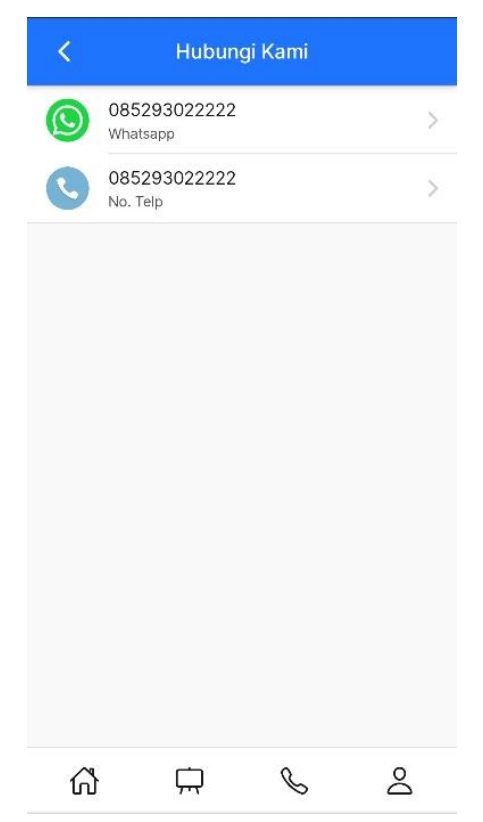

Gambar 11. Layanan Call Canter

untuk mencapai pelayanan yang maksimal terhadap ibu hamil kami sediakan layanan call center yang bertujuan untuk melakukan komunikasi langsung dengan bidan desa maupun petugas kesehatan.

\section{SIMPULAN}

Dalam konsep transformasi digitalisasi terhadap konsep smart village terutama di bidang kesehatan diperlukan strategi atau cara untuk melakukan edukasi dan konseling gizi dalam upaya program percepatan penurunan stunting di wilayah Kecamatan Mondokan. Dengan memanfaatkan teknologi digital yang bisa diakses melalui gadget atau PC. Platform aplikasi edukasi stunting dibuat untuk mempermudah penyampaian informasi edukasi dan konseling kepada masyarakat. Fitur-fitur yang tersedia dapat digunakan untuk memantau pertumbuhan dan kesehatan balita dan ibu hamil. Informasi edukasi gizi yang disediakan bisa diakses kapan saja dan dimana saja. 
Dengan aplikasi ini diharapkan masyarakat bisa melakukan penggalian informasi terbaru dan layanan secara digital terhadap risiko balita stunting. Fitur edukasi gizi pada ibu hamil, bayi dan balita akan memudahkan masyarakat memperoleh informasi tentang permasalahan gizi yang dihadapinya sehingga risiko kejadian stunting bisa diintervensi sejak dini.

\section{DAFTAR PUSTAKA}

Hasibuan, M., Sutedi, Lestari, S., Chairani, \& Wasilah. (2021). FRAMEWORK PEMBANGUNAN SMART VILLAGE INDONESIA (SVI). Prosiding Seminar Nasional Aplikasi Sains \& Teknologi (SNAST), E-143.

Agus Suryanto, O. P. (2017). SISTEM LAYANAN MONITORING STATUS GIZI ANAK BERBASIS ANDROID TERINTERGRASI DENGAN WEB. Jurnal Sain dan Teknologi , 1-12.

Aryastami, N. K., \& Tarigan, I. (2017). Kajian Kebijakan dan Penanggulangan Masalah Gizi Stunting di Indonesia. Buletin Penelitian Kesehatan, 234.

Gladys Apriluana, S. F. (2018). Analisis Faktor-Faktor Risiko terhadap Kejadian Stunting pada Balita (0-59 Bulan) di Negara Berkembang dan Asia Tenggara. Jurnal Media Litbangkes, 247-256.

Hendryani, A. (2020). Pengembangan Aplikasi Mobile Health Berbasis Android untuk Monitoring dan Evaluasi Stunting. Jurnal Sehat Mandiri, 24-32.

Ikhlaashi, S., \& Putro, H. P. (2019). Komparasi Dua Teknik Black Box Testing: Equivalence Partitioning dan Boundary Value (Studi Kasus: Aplikasi Postcrossing). Annual Research Seminar (ARS) 2019 (p. 214). Palembang: Fakultas Ilmu Komputer UNSRI.

Kurniawati, P. (2018, Oktober 29). Medium. Retrieved from Pengujian Sistem: https://medium.com/skyshidigital/pengujian-sistem52940ee98c77\#: :text=Black\%20Box\%20Testing\%20atau\%20yang,struktur\%20internal\%20kode\% 20atau $\% 20$ Program.\&text=Akses $\% 20$ kode $\% 20$ tidak $\% 20$ diperlukan, antara $\% 20$ perspektif $\% 20$ pengg una\%20dan\%20pengembang

Meidiawani, M., Misnaniart, \& Syakurah, R. A. (2021). KEPUASANPENGGUNAAPLIKASIE-PPGBM BERDASARKANKUALITAS SISTEM MODEL KESUKSESANDeLone -McLean. PREPOTIFJurnal Kesehatan Masyaraka, 97.

RI, K. K. (2018). Pedoman Proses Asuhan Gizi Puskesmas. Jakarta: Kementerian Kesehatan RI.

RI, K. K. (2019). KURIKULUM PELATIHAN KONSELING PEMBERIAN MAKAN BAGI BAYI DAN ANAK (PMBA). Jakarta: KEMENTERIAN KESEHATAN REPUBLIK INDONESIA.

RI, K. K. (2020). PEDOMAN PELAYANAN GIZI Pada Masa Tanggap Darurat Covid-19. Jakarta: KEMENTERIAN KESEHATAN REPUBLIK INDONESIA.

Soetjiningsih, G. R. (2013). Tumbuh kembang anak. Jakarta: EGC.

Sulismadi Sulismadi, W. W. (2017). Model Penguatan Kapasitas Pemerintah Desa dalam Menjalankan Fungsi Pemerintahan Berbasis Electronic Government (E-Government) menuju Pembangunan Desa Berdaya Saing. Jurnal Aristo, 216-258.

Supariasa. (2013). Penilaian Status Gizi (Edisi Revisi). Jakarta: EGC. 